\title{
On the Repugnance of Customary Law
}

\author{
MELISSA DEMIAN \\ State, Society and Governance in Melanesia Program, College of Asia and the \\ Pacific, Australian National University
}

Law, emerging from savagery, could know, absorb, and deracinate the savage impulses, rendering savage contents of blood and soil, violence and nobility as universal and exemplary, and setting them in enduring opposition to a savagery henceforth condemned to the local and base (Fitzpatrick 1999: 47).

The possibility of repugnancy would appear to have little practical importance where the Commonwealth Government is in complete control of the legislative process, as it is in all the territories except Papua and New Guinea (Roberts-Wray 1966: 408).

This essay is an exercise in taking seriously an item of constitutional rhetoric from Papua New Guinea (PNG), and also in asking how a standard legal instrument can become part of the moral repertoire of a wider community of interlocutors. If people in most state-centered legal systems understand the law to address social values - in the way that law is imagined to change either in the wake of a moral system or in "activist" endeavors to alter that systemthen the instance of the repugnancy clause in the Constitution of Papua New Guinea provides a salutary example of how this process might work for the cosmopolitan elites of a particular national context. In exploring this example I will also ask broader questions about the moral and legal status of a category that has had an enduring currency in a number of jurisdictions since the decolonization period of the mid-twentieth century. The category is "customary law," which in turn carries with it a version of an even more widely encountered concept in the postcolony, "custom."

In the course of previous research into contemporary criminal law in PNG, my attention was seized by an apparent fondness on the part of PNG judges for

\footnotetext{
Acknowledgments: Field research upon which parts of this article are based was funded by British Academy grant no. SRG-49399. The development of the final article was assisted incalculably by its presentation to the University of Kent Social Anthropology Reading Group, and to the Melanesia Research Seminar at the British Museum. I would particularly like to thank Marilyn Strathern, Lawrence Kalinoe, Ilana Gershon, Sue Farran, Judith Bovensiepen, and Adam Paliwala, as well as the anonymous reviewers for $\mathrm{CSSH}$, for the helpful commentary they have provided and that I have endeavored, to the best of my abilities, to integrate. My special gratitude is extended to Chief Justice Sir Salamo Injia and Justice Panuel Mogish for the material I have included from interviews conducted with them.
} 
the verbatim importation of one particular phrase from the country's Constitution into their decisions. The phrase is "repugnant to the general principles of humanity," and it appears in the following context, from Schedule 2, Section 18 of the Constitution of the Independent State of Papua New Guinea (Independent State of PNG 1975):

Sch. 2.1.1. Recognition, etc., of custom.

(1) Subject to Subsections (2) and (3), custom is adopted, and shall be applied and enforced, as part of the underlying law.

(2) Subsection (1) does not apply in respect of any custom that is, and to the extent that it is, inconsistent with a Constitutional Law or a statute, or repugnant to the general principles of humanity.

It may be that this phrase continually leapt out at me because I was in fact interested in how the category of customary law was enrolled in the legal consciousness of metropolitan or elite Papua New Guineans. But to the best of my knowledge, there is no other phrase from the Constitution that has been so faithfully and consistently reproduced by the judiciary since PNG's independence in 1975. It is also worth noting that the members of the judiciary who invoke this phrase are as likely to be Papua New Guineans as expatriates; if anything it has been even more popular with Papua New Guinean judges than it was with their foreign predecessors.

I therefore want to clarify that insofar as I might seek to represent an ethnographic perspective on the usage of repugnance in the PNG legal context, this usage and the perspective it indexes is an elite perspective. Whilst practices attributed to ancestral values and their place in contemporary life indubitably form part of a wider national conversation in PNG, and also find expression in myriad localized debates, the very grounding of the issue in law and its further framing as a problem for law marks it out as a problem of a particular kind for the metropolitan members of PNG society. To orient the discussion of repugnance philosophically, as I will do later in this article, would not make sense if I were speaking, for example, of the rural community in which I originally conducted fieldwork. But it is absolutely vital in order to acknowledge the way that an entire inventory of European philosophical traditions-legal, religious, political, and scientific - is available to the opinions of judges in PNG. Judges and other legal officers, as metropolitans, inherit a set of methods that a centralized elite, first colonial and now indigenous, have long employed to manage its relationship with a diverse and (in its view) unruly population. The repugnancy clause and its recurrence in case law are one manifestation of such methods that I find useful for the ways in which it permits an unfolding of the history of the relationship.

To embark upon this unfolding, it is firstly important to recognize that repugnance is actually the legal term of art when one is talking about antinomy - any circumstances in which a conflict within or between legal provisions arises - and as such repugnance can be invoked in an entirely 
neutral, amoral way. One can for example say that two clauses of the same contract are repugnant to each other, or that one piece of evidence contradicts a previous piece so that it is repugnant to that first piece, or that an item of the common law is repugnant to an item of constitutional law so that the common law will have to change accordingly. But this strictly legal meaning of repugnance appears to have acquired a new set of moral contours, as it became a recurring feature of colonial law.

The earliest expression I have found of the repugnancy clause in this form, and used in an analogous context, appears in an 1849 ordinance of the Colony of Natal, where "It was provided that customary law was to be preserved except where it was 'repugnant to the general principles of humanity recognized throughout the whole civilized world"” (Rubin 1965: 201). Whilst the PNG repugnancy clause almost certainly has its origins in African colonial ordinances of this kind, there is also ample evidence that repugnance was widely used as a legal instrument for the management of a hierarchy between European, colonial, and indigenous moral regimes. In his discussion of the history of repugnance between colonial and British laws during the heyday of the British Empire, Roberts-Wray (1966) deals with the concept in its nonmoral, strictly legal sense, until mention is made of an 1857 opinion by the law officers of the Crown on a Hong Kong ordinance in which "they advised that a law would be 'repugnant' if it prohibited Christianity or permitted slavery, polygamy, punishment without trial or the 'uncontrolled' destruction of aborigines" (ibid.: 401). The movement of legal repugnance into a moral domain as it pertained to colonial law appears therefore to have gained momentum, if it did not actually originate, in the middle of the nineteenth century. What is interesting about the law officers' opinion is that it applied to the laws of the Crown Colony of Hong Kong itself; it was not until somewhat later that such a moralized use of repugnancy was applied solely or consistently to the "customary law" of colonized peoples, as had already happened in the Colony of Natal.

Repugnancy clauses like that in the Natal ordinance appeared in numerous forms in the laws of most if not all British colonies in sub-Saharan Africa (Allott 1970: 158; Leslie 1977: 125; Bennett 2004: 64), with the explicit purpose of placing limits on the applicability of practices categorized as customary law (or in an earlier formulation, "native law and custom") where these were seen to conflict with the common law in particular and European values in general, coded variously as "natural justice," "morality," "equity," "accepted standards of ethics," and so on (Leslie 1977: 117). Allott (1970), in particular, demonstrates how the ordinary instrument of repugnancy may actually have acquired its moral value through colonial ordinances and their application in the case law of the then-British colonies. In a consideration of the various "categorical assertions" (ibid.: 159) by means of which repugnancy clauses were worded throughout British territories in Africa, Allott works through the categories of natural justice, equity, and finally morality. This 
latter category satisfies him the least as an arbiter of repugnancy because of the almost immediate recognition in many colonial African jurisdictions that, apart from banning slavery and non-consensual marriage (topics to which I will return), it was felt inappropriate even by colonial courts to try to map everyday British standards of "morality" onto legal decisions in Africa. In other words, the moral usage of repugnance was no sooner introduced to the statutory landscape than it began to lose traction with the courts, which seemed peculiarly reluctant to apply the respective repugnancy provisions of their jurisdictions. Read (1972: 180) offers an array of reasons for this phenomenon, ranging from increasing liberalization of the colonial judiciary to a lack of interaction between the "traditional and the imported legal systems," such that the latter had few opportunities to apply the repugnancy provision to the former. He prefers, however, the explanation that customary law itself was changing so much under the conditions of the colonial era that the need for a repugnancy clause was obviated.

For these and no doubt other reasons, the years directly preceding decolonization in Africa largely saw the removal of repugnancy provisions, beginning with Ghana and Tanganyika in the 1960s and exemplified in a more recent report from the South African Law Commission:

Although colonial authorities both here and elsewhere in Africa were prepared to tolerate customary law, they would not enforce rules that might offend European standards of morality and justice. South Africa's current statute on recognition continued this tradition. Section 1(1) of the Law of Evidence Amendment Act declared that courts may take judicial notice of customary law, "Provided that [it] shall not be opposed to the principles of public policy or natural justice: Provided further that it shall not be lawful for any court to declare that the custom of lobola or bogadi or other similar custom is repugnant to such principles..." (South Africa Law Commission 1999: 2.2).

The report goes on to observe that the repugnancy provision was rarely invoked even in the colonial and apartheid eras, but expresses concern that it might become a tool used by activist judges in the future, and further that it is anachronistic and reduplicates in extremely vague terms what is stated more clearly in the country's Bill of Rights. Many African jurisdictions appear to have embraced the recommendation found at the close of the report, that the repugnancy provision be discarded since it is "an unwelcome reminder of the superior role enjoyed by the common law in South Africa's legal system" (ibid.: 2.15).

In an interesting parallel with the British practice, colonial law in the Dutch East Indies applied a repugnancy clause to any article of adat (customary) law "if its application would be contrary to accepted human values. In these cases the judge was not allowed to replace the local adat law with the Penal Code, but he had to take that into consideration and to judge 'as a good father' or 'a reasonable man"' (Slaats and Portier 1993: 140). As Lev (1985) has observed, the very structure of the Dutch "recognition" of adat 
brought adat under the control of and limitation by the colonial legal system - a process that, arguably, happened everywhere that something called "customary law" was called into being and reified by a colonial legal regime. The use of the repugnancy clause in these regimes was in many ways simply a restatement or literalization of what had happened already, in the structural or scale-generating sense of an introduced legal system encompassing a social system that, in being so encompassed, is made to occupy a lower place in the scale of the encompassing system (Wastell 2007).

While inheritors of such encompassing systems from South Africa to Indonesia have discarded this particularly idiosyncratic index of scale or hierarchy, PNG has not done so. There, it is possible to trace the constitutional repugnancy clause to the Native Customs (Recognition) Ordinance 1963, and before that, to the Laws Repeal and Adopting Ordinance 1921 of what was then the Mandated Territory of New Guinea. In the Territory of Papua there was no comparable item of legislation (Weisbrot 1988: 4) or indeed any sign in the reception ordinances for the territory that British authorities intended to grant any legal recognition to local norms or practices (Ottley 1995: 99). It is certain, given the prevalence of repugnancy provisions elsewhere in the colonial legal repertoire, that the genealogy of the repugnancy clause predates its appearance in the laws of either of the territories that were combined to form Papua New Guinea. But for the purposes of my discussion, the following two points are of interest: firstly, unlike most constitutions drafted during and after the mid-twentieth century period of decolonization, PNG's kept its repugnancy clause, entirely unqualified and unaltered from its original wording. And secondly, the repugnancy clause crops up with intriguing regularity in this unaltered state in the legal utterances of Papua New Guinean judges.

I would therefore like to pose a series of questions about why this collocation has proven so compelling in PNG case law. Most obviously, it is compelling because of the somewhat fraught position that custom occupies in Papua New Guinean law. Custom is enshrined in the Constitution as part of the "underlying law" of the country; this status was reaffirmed and, in theory, revalorized in the Underlying Law Act 2000 (Independent State of PNG 2000). As multiple observers of PNG law have already observed (Corrin Care and Zorn 2001; Ottley 2002; Weiner 2006; Demian 2011), there are two interesting aspects to this Act. One is that it directs courts to apply themselves more assiduously to the task of determining which aspects of custom will form part of the "underlying law" of the country, and to do so by deliberately privileging an item of custom over an analogous item of the common law unless it is in conflict with a written law, or "its application and enforcement would be contrary to the National Goals and Directive Principles and the Basic Social Obligations established by the Constitution" (Underlying Law Act 2000: s 4). Needless to say, this does not have quite the same ring as "repugnant to the general 
principles of humanity," and judges have continued to pass over the clearer but blander phrase in favor of the more ambiguous but also more forceful one.

It is precisely the ambiguity and force of repugnance that I will explore here. Repugnance has become a powerful concept to apply to any item of law, customary or otherwise, and I will argue that neither its original inclusion in the Constitution nor its consistent reiteration since then have been accidental. Judges in PNG are not using repugnance in its strictly legal sense, but instead in the morally freighted sense that it acquired in colonial law as it pertained to customary law. In other words, these judges appeal to repugnance in the sense of disgust, distaste, or repellence, with only very attenuated echoes of its original Latin meaning of resistance. ${ }^{1}$ Some judges in fact appear to shift between the two senses of the term, but nowhere, when repugnance is applied to customary law, is it used only in the legal sense. Disgust, repulsion, and horror are always lurking in the background, and emerge momentarily when judges dwell upon the more distasteful details of criminal cases in which custom is pleaded. But as I will suggest later, with the help of some of the currently prevalent theories of disgust, disgust and horror invariably index their opposite-desire and fascination. It is from this antinomy that PNG judges must derive a resolution.

I will contend that Papua New Guinean judges have adopted as part of their remit the task of working out which practices pleaded as customary law pass or fail the repugnance test, and that this is not simply a test of legal compatibility or harmonization. It is certainly, among other things, a test of what kinds of practices educated, middle-class Papua New Guineans can bear to tolerate in the liberal nation state they seek to build (Banks 2001); it is an exercise in imposing limits on the behavior of the "grassroots," as rural people in PNG are commonly known. But it may also, as I will suggest later, point to some deeper preoccupations Papua New Guineans have concerning their historical and ongoing relations with Europeans. I have accordingly adopted as part of my remit the task of establishing what it is, precisely, that makes certain practices identifiable, first, as custom, and second, as repugnant.

My exploration will proceed as follows. Firstly I will touch on the work of Elizabeth Povinelli, whose interest in the antinomies in which Australian courts attempting to recognize Aboriginal distinctiveness are caught is relevant to my own interest in the legal conundrums across the Torres Strait in PNG. One of the problems I hope to illustrate is how Povinelli's model of these antinomies, arising from Australia's efforts to present itself as a multicultural society, runs

\footnotetext{
1 "Repugnant" derives from the French répugnant, "contrary, opposed, in opposition, resistant," and ultimately from the Latin repugnare, "to resist or fight back," containing the root pugnare "to fight." According to the Oxford English Dictionary, the legal sense of the term dates to at least the fifteenth century, whereas the moral-aesthetic sense does not begin to appear until the seventeenth century and it acquires a fully-fledged connotation of disgust or aversion only in the nineteenth century. The less common verbal form, "to repugn," appears to have retained the original sense of resistance or opposition in its modern usage.
} 
into trouble in PNG, even though the colonial histories of the two countries are deeply enmeshed and implicated in one another. From there I will proceed to some exemplars of case law that demonstrate how repugnance is invoked in PNG courts and, crucially, in what kinds of cases. Finally, I will survey some currently available theories of disgust and shame, to assist in approaching the issue of custom's repugnance in a way that is not locked into colonial or neocolonial discourses. These theories will also inform my conclusion that judges in PNG have used the repugnancy clause in order to move their frame of reference away from a constant reflection on their country's legal past and toward an anticipation of its future.

FRAMING REPUGNANCE AS A REFUSAL OF "RECOGNITION"

Povinelli's The Cunning of Recognition (2002) contains, to the best of my knowledge, the only other endeavor by an anthropologist to ask what the repugnance of customary law might suggest about the relationship between courts of colonial origin and people who participate in particular kinds of claims through such courts. It presents a version of the conundrum with which I have opened, namely, what are the mechanisms through which a legal or political metropole imagines its relationship with a diverse population requiring integration, again in the view of the metropole, into a particular vision of modernity. Finally, this book is an excellent example of the ease with which it is possible to elide the distinction between legal repugnance and its more common usage, because the latter offers much greater moral and political traction than does the former. That this elision of meanings can occur even in a work that deals specifically with the effects of legal discourse on the racial and cultural politics of a self-styled multicultural state - in this case Australia - is in itself instructive.

Povinelli's argument turns on the double bind in which contemporary Australian Aborigines are caught vis-à-vis native title, the putative legal solution to the injustices of colonial and more recent history. ${ }^{2}$ To successfully prosecute a native title claim to a place or territory, a group of Aborigines must demonstrate a distinctive and documented cultural continuity of language, religious life, residence, subsistence base, or some combination of these. However, as Povinelli notes, "The High Court held that "when the tide of history has washed away any real acknowledgment of traditional law and any real observance of traditional customs,' the foundation of native title disappeared and native title rights were extinguished" (ibid.: 164). These requirements for

\footnotetext{
2 The Native Title Act 1993 was a consequence of a series of landmark cases in which Aboriginal claimants succeeded in a legal repudiation of the doctrine of terra nullius, whereby Australia had been deemed as having neither occupiers nor owners during the era of European settlement. While the Act was seen as the most profound shift in Australia's legal landscape since colonization, it had limited effects on Aboriginal peoples' abilities to recover sovereignty over any of the territory lost to them through colonization. For discussions of this, see, for example, Strelein 2004, and Motha 2005.
} 
successful claims under the Native Title Act are then placed alongside the historical and current "repugnance"-Povinelli's term - of Australian courts for certain Aboriginal practices deemed customary, notably those involving polygamy, sexual or violent acts within ritual contexts, and the marriage of children. In other words, to lodge a native title claim, Aborigines must embody what Povinelli calls "distinct culture" but not "repugnant culture" (ibid.). The first authenticates their claim as Aborigines; the second disqualifies them from treatment as citizens of the modern liberal state.

Povinelli further documents the Australian national discussion of its obligations to Aborigines in terms of the avoidance of shame, or repugnance, at the position required of it to acknowledge that the very laws now imagined to rectify past injustices are part of the same liberal legal tradition that committed them, as she asks, "How, in short, do courts side-step the problem of accounting for justice in the breach and shadow of the court's own repugnant and shameful history?" (ibid.: 155). So the breach maintained by courts between "distinct culture" and "repugnant culture" also serves the purpose of purifying the contemporary liberal state from the ignominy of its own actions in the not-so-distant past. As Povinelli later suggests, "If the court forestalls its own fall into the breach of history, it does so by pushing Aboriginal persons over the cliff. In actual given instances of historical time, if the court feels 'repugnance' it understands it to be generated from, or be an essential part of, Aboriginal customary practices rather than understanding the feeling of repugnance to be generated from the discursive mandates and contradictions of liberal injunctions" (ibid.: 179).

This passage points to the relevance of Povinelli's work to my discussion. In it, she makes a theoretical move that PNG courts also make, only they do it in practice rather than as a critique of practice. That is, the negation of any distinction between legal repugnance and moral or personal repugnance lends repugnance a double antinomy: not only does repugnance simultaneously repel and attract, but the fact that it can mean both a conflict of law and a conflict within the person has the interesting effect of causing Australian law, and in particular Australian land claim tribunals, to appear as kinds of persons. The result of this move is that in Povinelli's formulation, courts as institutions can feel repugnance. Although she does not make its origins explicit in her discussion, Povinelli appears to have imported the concept of repugnance itself from an Australian repugnancy clause, in the landmark Mabo v. Queensland case that paved the way for the Native Title Act. The repugnancy clause in Mabo appears as follows: "The incidents of a particular native title relating to inheritance, the transmission or acquisition of rights and interests on death or marriage, the transfer of rights and interests in land and the grouping of persons to possess rights and interests in land are matters to be determined by the laws and customs of the indigenous inhabitants, provided those laws and customs are not so repugnant to natural justice, equity and good conscience 
that judicial sanctions under the new regime must be withheld" (Mabo $v$. Queensland (No 2), [1992] HCA 23).

Having cited the last part of this clause, Povinelli then asks, "Why would the High Court insert this rider to their recognition of customary law as the basis of native title? Why would these justices ... think that some Aboriginal customary laws might be repugnant" (ibid.: 108). There are at least two answers to this question. One is that repugnancy clauses have always been a part of the heavily qualified and circumscribed integration of "customary law" into colonial law, and the second is that there may be a misconstruction here of what a repugnancy clause actually means and does in legal terms. It is probably not the case that, as Povinelli implies, Australian courts simply find Aboriginal practices disgusting. Or perhaps they do, and there may even be good evidence that they do, but not, I submit, in the singularly personified fashion with which she sets out the problem. Again, what is of interest here is not so much an issue of the elision of meaning in a legal instrument, but that what Povinelli does in her analysis of Australian native title, PNG courts do in practice.

The constitutional and statutory issues at stake in PNG have been both shadowed by, and starkly distinct from, those in Australia. In common with many Pacific nations, PNG's colonial history is complex. British and German interests were established on the eastern half of the island of New Guinea toward the end of the nineteenth century. British New Guinea was handed off to Australian control in 1902, after which it became known as the Territory of Papua. Following the First World War, German New Guinea came under Australian military authority and then a League of Nations mandate, governed by Australia, as the Mandated Territory of New Guinea. While the latter retained some German colonial policies and legal framework, the combined entity that became the Independent State of Papua New Guinea in 1975 is a common law jurisdiction, and remains a member of the Commonwealth, due more to its longstanding association with Australia than to an earlier, brief, and partial association with the United Kingdom. Critically however, PNG never became a settler state in the way that Australia did; it is almost entirely populated and governed by its own indigenous peoples. Furthermore, at least 85 percent of land in PNG is still held under customary tenure, and customary land claims were a common feature of the legal landscape well before independence. However, PNG was until 1975 subject to the laws of the settler state next door, and this had obvious effects, not least of which was the repugnancy clause.

More fundamentally, however, the PNG struggle with the problem of customary law is not usually one of authentication, as Povinelli argues that it is for Australia (and see also Bell 1998; Weiner 1999). The exception that springs to mind is when judges doubt the veracity or accuracy of litigants' pleadings of customary law-but even here it is not because they cannot demonstrate that 
the custom has persisted since time immemorial, but rather because it is vaguely stated, is contested by different witnesses, seems internally inconsistent, or otherwise appears insufficiently rule-like (Demian 2003). Although anthropologists long argued that these are precisely the defining set of characteristics that delineate "customary law" (e.g., Malinowski 1926; Llewellyn and Hoebel 1941; Gluckman 1956), I would like to suggest that instead of turning upon the authentication of indigeneity, which is not an issue in PNG, customary law has taken on both differentiated and undifferentiated forms in the view of the courts and individual legal practitioners: differentiated in that each place is assumed to have its own particular custom, undifferentiated in that all places are assumed to have their custom, and that the custom of each place is imagined to be analogous to law, such that it can be regularly deployed by magistrates in a Village Court or pleaded as evidence in a District Court or National Court. This is why custom could be enshrined in the Constitution as a trait characteristic of PNG as a nation, and why it is now supposed to be more vigorously developed as a component of the underlying law (Filer 2006; Weiner 2006; Demian 2011).

I will unfortunately have to set aside for the time being the problematic nature of the proposition that all peoples in PNG "have" custom, because my original research was with a group of people who claimed quite vigorously that they did not have theirs anymore (Demian 2006), and Melanesian peoples understand more generally the need to "translate" or "simplify" practices they might call custom for the benefit of outsiders (Hviding 1993). For the purposes of this article I am dealing with the undifferentiated form of custom, which is to say that custom is made analogous to law, such that custom can either become a version of law or be deemed repugnant to law. (And in this way it again becomes differentiated: custom is not a stable-state technology.) What remains is to examine how this process occurs in practice. Because if determining the repugnance or otherwise of custom is not a matter of "recognizing" it, then the durability of PNG's repugnancy clause remains to be explored. Clearly it is a tool meant to accomplish a particular kind of work, but what kind of work, exactly?

I will turn now to case law that demonstrates the movement of repugnancy between its legal and moral values. The cases I draw on here represent and illustrate categories of cases in which the repugnancy clause is cited almost invariably, and almost always verbatim. ${ }^{3}$

\footnotetext{
${ }^{3}$ Readers may notice the absence here of one category of case in which custom is regularly pleaded, and that is, ironically, the customary land claim. Land claims by means of custom appear exceptionally un-repugnant, in either sense of the term, to PNG courts. The only problem that crops up in regard to custom in these cases is in what form, for instance, people are to be compensated for land that was wrongfully alienated during PNG's colonial era. I have yet to find a land claim case in which the repugnancy clause was cited.
} 


\section{A LIFE HISTORY OF THE REPUGNANCY CLAUSE IN SEVEN CASES}

This section aims to answer two questions: what types of cases have been found to merit use of the repugnancy clause by District Courts and National Courts in $\mathrm{PNG}$, and how has the use of the clause changed over time? A close observation of the movement of the clause through case law since PNG's independence is key to understanding how the clause has become a way-if not the preeminent way - for judges in PNG to frame their relationship to the category of custom, and thereby the location of custom itself within a particular hierarchy of value.

I will start with more predictable categories of cases, and move on to those that may less obviously offer themselves to invocation of the clause. In order to get the most sensational type of repugnancy-meriting case out of the way, I begin with State v. Aubafo Feama, Nama Auri, and Kafidiri Kududebe Hagima, heard at Daru in the Western Province in 1978. I had to go back to 1978 to find a cannibalism case, but it usefully displays some of the problems confronted by the judiciary of what was then a newly independent state.

Officially, the three defendants were charged with "misconduct with regard to corpses." Specifically, their "misconduct" took the form of interrupting the burial of two men in a neighboring village, cutting some flesh from the bodies of the deceased, and taking it home to cook and eat. There were testimonies to all of these actions by what the judge deemed to be reliable witnesses, including the kin of the dead men whose burial was so peremptorily interrupted.

The presiding judge, a Justice Wilson, gave an account designed to illustrate the disparity of experiences of ordinary Papua New Guineans vis-à-vis the law in PNG. The three accused were from the Nomad River region of Western Province, at that time an impenetrable backwater. The defendants were uneducated, not Christians, and indeed had had almost no contact with representatives of state authority until their trial. The judge said he was given to understand by his witnesses that cannibalism was locally associated with preparations for becoming a sorcerer, and also that the practice was in decline.

Justice Wilson then went on to note that since this was the first postindependence trial for cannibalism, it was incumbent on him both to hew closely to the new Constitution and to set a precedent for how this sort of case would be regarded by the young state. So after a lengthy consideration of what was meant by "improperly interfering with a corpse," and placement of this discussion alongside the provisions of the Customs (Recognition) Act and the Constitution, he concluded:

However strong the evidence of custom might have been (and it must be noted that it was not strong here), such a custom, in so far as it condoned acts of cannibalism, could not be adopted and applied in this Court, because unquestionably it is repugnant to the general principles of humanity and, as this judgment so finds, it is unlawful. It is 
unnecessary to attempt to define or to attempt to specify what those general principles of humanity are. To answer the question of whether certain conduct is repugnant to the general principles of humanity all that one needs to do is to see if one can reconcile the concept that it is permissible for a person to cut up, for eating purposes, the dead body of a man with the notions contained in the Constitution. Undoubtedly there can be no reconciling of the two (State v. Feama, Auri, and Hagima [1978] PNGLR 301).

So at first glance it appears that Justice Wilson was in fact applying the strictly legalistic sense of "repugnance" to the case. Except that he then proceeded to cite the Preamble of the Constitution, in which it is stated that the framers of the Constitution "acknowledge the worthy customs and traditional wisdoms of our people." The judge concluded from this construction that lawmakers were thereby invited expressly to draw a distinction between worthy and unworthy custom, and that this case presented him with an opportunity to do so. He therefore found them guilty as charged, in order to communicate that the new state would not tolerate the custom, if any, of eating the dead. However, given the youth, "lack of sophistication," and lack of prior convictions of the accused, he imposed on each of them a sentence of just fifteen months.

The presumed degree of a defendant's "sophistication" or "civilization" figures also in State v. Maraka Jackson, a 2006 case in which the National Court was faced with the kind of murder trial that PNG courts face with disheartening frequency. Sorcery-related killings in PNG have seen a marked rise in both number and violence in recent years (Forsyth 2013). The most immediate response to this phenomenon has been the repeal of the Sorcery Act 1971 by the PNG Parliament, as the vague wording of the Act was deemed to provide murderers with a ready defense in the name of custom. This case was precisely the kind of case in which the Act was seen to figure unhelpfully.

Jackson, a twenty-five-year-old villager from the Gulf Province, had killed an older man, Maura Purari, with a bush knife. Jackson testified that he did so because Purari had killed some of his kin with sorcery, and Jackson feared he himself would be next. That Jackson had committed the murder was not in question, since he readily pleaded guilty to having done so. The problem facing the judge in this case was one of sentencing, as it nearly always is in cases when the defendant claims he (it is always he) was killing a sorcerer. The Sorcery Act 1971 (Independent State of PNG 1971) provided for the fact that the overwhelming majority of the population finds the reality of sorcery unquestionable with the following sort of language: "Sometimes people may act, or may believe they are acting, under the influence of sorcery to such an extent that ... their conduct may not be morally (and should not be legally) blameworthy" (Sorcery Act 1971 Preamble). Justice Kandakasi cited this element of the act, but also a later paragraph in which it is cautioned that people may make malicious accusations of sorcery merely for the purpose of getting another person into trouble, or worse, excusing 
their own violence toward that person. It is this section that appeared to concern the judge throughout his decision.

Although he noted that previous cases of sorcery-related homicide resulted in diminished sentences, he departed from the practice of his colleagues with the following statement:

The only thing that makes sorcery related killings special is the believe [sic] in sorcery. However, sorcery is neither a fact that can easily and readily be proven or refuted. It is a matter of what one wants to believe and not. The Sorcery Act provides for the way in which people suspected of sorcery should be dealt with. It does not say that those who kill on believe [sic] of sorcery should be given special treatment. To do so would be to give sanction and to license some of the most vicious, brutal, merciless and public execution type killings that have thus far occurred. Sorcery is a belief based on custom. The Constitution in Sch. 2.1 (2) dictates that we should retain only those customs that are not inconsistent with a written law and are not repugnant to the general principles of humanity...Killings in whatever form or manner, except as may be provided for by law, is a prohibited act worldwide because it is against the general principles of humanity (State v. Jackson [2006] PGNC 154).

Having declared killing in alleged vengeance for sorcery repugnant, the judge then went on to invoke factors which derive directly from colonial-era sentencing practices (Dinnen 1988): he took into account the level of "civilization" of the defendant by noting that he had a primary school education, was an avowed Christian, and came from a village that was close to the provincial capital of Kerema. In other words this was no country bumpkin, or the sort of person whom pre-independence expatriate judges would not have hesitated to call "primitive." Having listed all these factors, not to mention various aggravating factors (the killing was clearly premeditated; the accused had conspired with a friend and waited for his victim to come out of his house in order to attack him), the judge finally concluded that the belief in sorcery did not "deprive you of any rational thinking and fail to give you an opportunity to think before acting," and sentenced Jackson to twenty-four years in prison.

Another category of declared custom that PNG courts have consistently declined to legitimate has appeared in cases in which certain conditions of marriage are deemed to have been enforced on a woman against her will. Three cases briefly discussed will illustrate this point. The first two are both from 1991 and involve women who had been imprisoned by their respective Village Courts in the country's Western Highlands Province.

In Re Kaka Ruk, the wife in question had been accused of adultery with her husband's younger brother, and ordered to pay compensation. She countered that her husband had left her to work on a plantation, that they had no children, and that in any event she had no income with which to pay compensation. The Village Court ordered her imprisoned, and the case was appealed to the National Court. Justice Woods declared her imprisonment unlawful, citing the Constitutional repugnancy clause. In explaining his invocation of the clause, Justice Woods wrote: "This custom that the husband is seeking to 
apply which leads to her jailing when he is in the dominating position and where the situation has been partly caused by his behaviour must be a custom that denigrates women and is thus repugnant to the general principles of humanity and should be denied a place in the underlying law" (Re Ruk and Constitution S42(5) [1991] PNGLR 105).

Earlier the same year and in the same jurisdiction, Justice Woods heard a strikingly similar case from another village. A woman named Wagi Non had been imprisoned by her Village Court, again for an adultery conviction for which she was unable to pay compensation. And again the husband had gone to another province in search of work and left Wagi Non with his relations, remitting no money to her to help support their children. The husband was in fact so thoroughly incommunicado that the adultery accusation was actually brought by his kin rather than himself. But again, although he did not in this instance cite the repugnancy clause, Justice Woods also found the imprisonment order unlawful because "The facts of this case suggest that this woman is bonded, almost in slavery, to the husband even when the husband neglects her. This must clearly be a denigration of the woman's humanness" (Application by Non [1991] PNGLR 84).

Readers should bear in mind that analogy to slavery as I describe the final case in this trio, Senan Ess Olwen v. Lucy Tiso, from 2003. This case, too, comes from the Highlands, although from a different jurisdiction from the first two. Lucy Tiso had been married to Senan Olwen for six years when she left him for unspecified reasons. A series of Village Court hearings followed, from which Olwen apparently received no satisfaction, since he then applied to the District Court and asked it to order Tiso to return to him.

The District Court Magistrate Mr. Tat Akali lectured the plaintiff that marriage, whether in a church or by custom, was characterized by its voluntary nature, and even went so far as to cite a dictionary definition of "voluntary." He then observed, "In the customary sense in the PNG highlands wives are considered as the property of the husbands and are in that marriage relationship because the women were bought at a considerable price.... In this case the recognition of this custom that women are the property of men, would be an injustice and is certainly not in the public interest of the right and liberal thinking members of the public. This custom and practice is repugnant and must be discouraged wherever and whenever we are able to" (Olwen v. Tiso [2003] PGDC 34). After noting that the "noble traditions" of the country also had to be reconciled with the adopted principles of Christianity, which the application signally failed to do, he declared the application misconceived and disallowed it.

Related ideas about the appropriateness of combining customary with adopted or introduced values have arisen in cases where child custody, or other forms of "disposition" of children, turned on the rights of the mother or the offspring in question. Robson Ubuk v. Rachel Darius was heard at the National Court in Lae, PNG's second city. In this case, Ubuk was suing for 
custody of the infant daughter Anita he had had with Darius, his de facto partner, who had left him. He already had a wife who, he said, was willing to raise Anita alongside their other three children. Crucially, Ubuk submitted a deposition from a senior man from his village of origin on Siassi Island, explaining that the custom of the Mailan people allowed for a man and woman to cohabit some time before bridewealth was expected, to make sure the woman would "be a good housewife" and bear children. If the couple splits before bridewealth is paid, and there is a child, then the woman forfeits custody of the child, although the woman has the right to claim compensation for having borne the child.

After some discussion of Anita's welfare and noting that she was the product of an adulterous relationship, thereby casting doubt on the applicant's claim that his wife would be happy to look after her, Justice Sevua turned to the issue of customary law. In point of fact Ubuk did precisely what one is supposed to do when pleading custom as evidence in PNG: he marshaled a person who could be identified as knowledgeable in the custom of his place, and was able to submit a deposition including this person's testimony. But this seems actually to have made it easier for Justice Sevua to disallow the customary law claimed, since he could make reference to and interpret specific items in the deposition, as follows:

If she cannot bear children, that's it, she cannot marry the man. In my view, she is being used as a vehicle for child bearing, because the only time you know if she can bear children or not is when she becomes pregnant. Whether one views it subjectively or objectively, the woman is a sex object. So where is the morality and value of humanity in this woman? How does the custom accord with the general principles of humanity? How does a woman in such a situation free herself from this seemingly sexual domination? I consider the Mailan customs repugnant to the general principles of humanity and, therefore, inapplicable to the present case. The applicant can gain no assistance from that customary law (Ubuk v. Darius [1994] PNGLR 278).

Justice Sevua accordingly awarded custody of Anita to Rachel Darius, although he granted her father access.

It is almost impossible not to mention a final and now iconic case in this category, although there is probably little I can add to an already formidable body of analysis of it (Gewertz and Errington 1999; Banks 2001; Strathern 2004; Merry 2009). This case, popularized in the PNG press as "Compo Girl," was properly titled In re Miriam Willingal, and took place over the course of 1996 and 1997. Compo is slang for compensation, a by now universal mechanism in PNG through which an injured party can extract an equivalent value for harm done from the putative wrongdoers, and one whose swiftly transforming nature has inspired much discussion amongst both policymakers and anthropologists (e.g., Filer 1997; Banks 1998; Strathern 1999; Demian 2011). In this case, a particular form of compensation was actually outlawed. Willingal is iconic because it is the first instance, to my knowledge, in which 
a court not only refused to legitimate a practice claimed as custom, but declared it categorically unlawful. In other words, the National Court did more than decline to make this putative custom part of the underlying law; it was decided that the practice could form part of no legal regime whatsoever in PNG. In some respects, the cases I have just described can be seen as leading up to it - they are not cited as precedents, but they form a pattern of which the decision in Willingal was undeniably a part.

The case is a complex one, because it was not a case of compensation alone, but rather compensation combined with a form of social organization familiar to anthropologists: prescriptive cross-cousin marriage. ${ }^{4}$ In 1996, Miriam Willingal hit the headlines in PNG newspapers as having been included in a compensation payment between two "tribes" (the term used in the case report) in Western Highlands Province, the Tangilka and the Konumbuka. Miriam's father was a Tangilka; her father's mother was a Konumbuka. Toward the end of a fifteen-year feud between these two groups, in 1996, Miriam's father was shot dead by police on Konumbuka land. Although it was a Tangilka who died, the Konumbuka blamed the Tangilka for bringing the police onto their land and causing the death of their daughter's son. Compensation was demanded, and included in this demand was the activation of an obligation to "return" a woman to the wife-givers, that is, to give a Tangilka woman back to the Konumbuka who had given their daughter to the Tangilka in the previous generation. In other words, the obligation was always latent in relations between the two groups, but the death of Miriam's father appears to have concentrated the minds of the Konumbuka such that they decided this would be an excellent time to settle the debt. Miriam was deemed the most appropriate candidate, but she was reluctant to marry until she had finished her education and found a job, and wanted a say in which Konumbuka man she would marry, if any. She solicited the help of an NGO, the Individual and Community Rights Advocacy Forum (ICRAF), which brought the case on her behalf.

The depositions in this case are fascinating but far too lengthy to explore here; they boil down to disagreement between different sorts of "experts" in the custom of the Minj region of the Western Highlands. But in the end the presiding judge, Justice Injia, noted the following in a considered and expansive decision:" "It seems ironic that traditional customs and customary practices

\footnotetext{
4 Cross-cousin marriage is marriage (described here from a female perspective) to one's father's sister's son or mother's brother's son, or other persons who are classified under these kinship categories. It is tempting to speculate whether, had the marriage prescription not become entangled with the compensation claim, this case would ever have gone to court, let alone made international news. I first read about it in the New York Times (Mydans 1997), in a piece clearly intended to inspire the reader with the tale of a forward-thinking young woman courageously defying the patriarchal traditions of her hidebound people.

5 Salamo Injia was deputy chief justice when I had the opportunity to speak to him about this and other issues in 2008; he was appointed chief justice later the same year. Somewhat to my chagrin he did not immediately recall Willingal until I described for him details of the case. This perhaps says
} 
of some ethnic societies should be struck down by the courts as being inconsistent with our national laws, that is, inconsistent with a constitutional law or statute or repugnant to the general principles of humanity, when those very customs and customary practices have their own values in their respective ethnic societies" (In re Miriam Willingal [1997] PGNC 7).

But, in finding that the custom of "head pay" (that is, including crosscousin marriage as part of a compensation agreement) violated the Marriage Act, the Customs Recognition Act, and the Constitution on the grounds that it discriminated between women and men as bearing different rights and obligations, Justice Injia did not actually have to cite the repugnancy clause. That he did so anyway is significant, if not surprising. In fact, his strategy was to show that by being repugnant - in the legal sense - to a particular category of statutes as well as to the Constitution itself, he could demonstrate that it was in fact repugnant to the general principles of humanity.

Within all the case law that I consulted for this research, Justice Injia was the only judge to note that the "general principles of humanity" have as yet gone undefined in PNG law, notwithstanding that his predecessor in the 1978 Feama case had declared it unnecessary to define them. As an interim solution to their vagueness of definition, he cited relevant precedents in which violation of the general principles of humanity seemed indisputable: cannibalism, payback killing, and the mutilation of adulterers. He then drew an analogy between these more sensational practices and the practice of "head pay" and went on to declare that "living men or women should not be allowed to be dealt with as part of compensation payment under any circumstances" (ibid.). The implication was that including a person as part of a compensation payment was tantamount to removing part of that person's body, devouring him, or killing him in revenge. These notions do not come out of nowhere, but stem from a Papua New Guinean and Melanesian ritual-philosophical suite of analogies between the transfer of persons from one social group to another (in marriage, adoption, or indeed compensation) and the destruction or consumption of those persons, whose bodies and capacities are in either case lost to their kinfolk. That Justice Injia was able to draw effectively upon these analogies is unremarkable. Perhaps more remarkable is that his judgment smoothly transitioned from such standard Melanesian concepts of personhood to a kind of personhood more familiar to those educated in the European Enlightenment tradition, in which the person is the sole arbiter and proprietor of her bodily integrity, and of her contractual relationships with others. This judgment illustrates with special clarity the problem presented to the legal

something about the way a case may achieve iconic status with academics but not with the judiciary itself, or it may simply say something about the very heavy caseload carried by National Court judges in PNG. 
elite of PNG by such unbuttoned appeals to custom as "head pay": they represent a version of personhood that is increasingly perceived by judges to be at odds with a particular conceptualization of the "human" lurking within "the general principles of humanity."

A number of themes may now have suggested themselves in my discussion of these cases. I will for the moment work with the following: the theme of sophistication versus unsophistication, the theme of safeguarding the humanity (defined as autonomous individualism) of victims or imagined future victims, and the theme of analogies to slavery. These are the topics I would ask the reader to keep in mind as I move on to the next section of this article, which is a consideration of how theories of disgust and horror might inform an understanding of how the repugnancy clause has been used in these and other cases in PNG. This is, after all, the latent meaning of repugnance now carried within every legal use of the term, as the work of Povinelli demonstrates implicitly and as I hope to have made explicit through the decisions of some of the PNG judges who have invoked the term. It is hard to avoid the repugnance of repugnance, the sense that to repugn a practice or principle is almost literally to hold its offensiveness at arm's length. It therefore seems necessary to embark on at least a preliminary exploration into how one might theorize repugnance not only as a legal instrument, but also as a particular affective mode that is a powerful tool available to judges to lend weight to their decisions on those actions pleaded as customary that they deem unacceptable to the hierarchy of value they are meant to be safeguarding. I will then conclude with some initial suggestions of what this form of affect might index in the PNG legal experience.

THE MORAL-AESTHETIC VALUE OF REPUGNANCE: DISGUST

In 1929, the Hungarian-born philosopher Aurel Kolnai published his brief phenomenological treatise on disgust, in which he made the perhaps obvious but crucial observation that disgust operates as both a physical and moral experience, such that one can be difficult to distinguish from the other. Furthermore, disgust as a "defense reaction" (2004: 30) is to be distinguished in several important respects from the related defense reactions of fear and anxiety, not least among which is the idea that disgust is a more aesthetically inflected experience, picked up on by later writers on the subject (not to mention earlier ones, such as Kant). But for my purposes, I take the following distinction to be of signal importance: "What is disgusting in principle is not threatening, but rather disturbing, even though a mere disturbance by itself, however strong, cannot evoke disgust. A thing which is perceived as disgusting will always be something which is not going to be regarded as important, which is neither to be destroyed, nor something from which one has to flee, but which must rather be put out of the way" (ibid.: 42, his emphasis). Here Kolnai observes that the denigration of the disgusting is precisely what demotes it from being an object 
of fear or anxiety, each of which would require a more extreme response than removing that which disgusts from view. Kolnai is also aware that the disgusting is simultaneously fascinating or alluring: "disgust is more immediately ambivalent than fear. It presupposes, as it were by definition, an (albeit suppressed) desire for the object which provokes it" (ibid.: 43, his emphasis).

Why should this be? Apart from the somatic immediacy of a constricted face as opposed to a scream of terror, there is what Kolnai calls the intentionality of the defense reaction. This is not intentionality in the sense of a presumed inner state, but in the philosophical sense of directedness toward an object. In the case of disgust, the direction of intention is "toward a disturbance of the existence of the subject brought about by alien existing objects" (ibid.: 45). The same might be said of fear, so again what distinguishes disgust is that "the object of disgust is prone to be connected with something which is concealed, secretive, multilayered, uncanny, sinister, as well as with something which is shameless, obtrusive, and alluring; that is, in sum, to be something which is taunting" (ibid.: 47). It is the dual nature of the disgusting, its hidden and blatant components, that render its proximity so disturbing, for the possibility that it might contaminate the subject is both threatening and enticing.

There is much more to Kolnai's account than this, not least of which is his intriguing notion that the decay, decomposition, and mortality associated with disgusting things is actually a response to the overabundance of life, an impinging of the teeming fertility of the world on the constrained experience of the subject. Setting aside the temptation to speculate that this might have more than a little to do with the resolutely urban and cosmopolitan life trajectory of the philosopher, the salient point here is that, for Kolnai, disgust is rarely if ever a response to too little of the world: it is on the contrary a response to too much.

Some seventy years later, William Ian Miller reinvented much of Kolnai's model, but began to draw out its hierarchical implications. In other words, Miller is interested in how disgust is a mechanism for the reassertion and maintenance of hierarchy, especially under the conditions of democracy. In particular, he enumerates the many historical cases in which marginal or subordinate categories of persons in Europe and the United States - manual laborers, women, Jews, and African Americans - have served as exemplars and embodiments of the disgusting. More interesting though is his discussion of the moral implications of disgust. As he notes, "The argument is not whether disgust operates in the moral domain, but about its proper scope, its proper object, and its reliability in that domain" (1997: 180). An avowed devotee of the Scottish Enlightenment, Miller goes on to invoke Adam Smith's "impartial spectator," a sort of null person that can be used to read off the development of any given perspective. This capacity of the impartial spectator is precisely what shows up again the ambivalence of disgust, as Miller asks, "Yet how does 
Smith's observer come to the judgment of impropriety unless he in fact imagines himself so acting? The knowledge that he would be seen in the same way as he saw such behavior makes whatever fantasy he constructs about so behaving so unpleasant that he abandons it in disgust ... as soon as he witnesses impropriety he is himself compromised by the imaginings he must undertake in order to disapprove" (ibid.: 192). Miller expresses reservations about his own conclusion here, since it suggests something more like shame than disgust, the anticipation of the disapproval of others. But the "shame morality" that disturbs Miller is precisely where another American legal scholar, Martha Nussbaum, picks up on the very real legal implications of the relationship between disgust, shame, and the law.

Nussbaum (2004) is even more determined than Miller to tease out the hierarchical implications of disgust, and to demonstrate how disgust has formed the basis for both defense strategies and legislative ones in American law. She disputes the possibility, raised by Miller and also by far more conservative commentators, that disgust forms part of some kind of primordial evaluative equipment that ought to serve as a moral compass in civic decisionmaking. Not only is it too subjective and unreliable a gauge of the accuracy of events, she argues, but it also subverts precisely what some theorists of disgust claim is the universal function of the disgust reaction: to reassure humans that they are not animals, or at least, that they are unique among animals. Nussbaum argues that not only is disgust unable to provide a universally reliable moral compass, but that when it is brought to bear in legal discourse, it serves more often than not to act as a tool of discrimination and marginalization.

Finally I would like to apply to the foregoing accounts of disgust the work of the literary critic Winfried Menninghaus. Menninghaus' whirlwind tour through the entire Germanic tradition of disgust as a fundamental aspect of aesthetics adds the dimension that is missing from both Miller's and Nussbaum's deliberations on the role of disgust in law and society. This is the aesthetic dimension itself, the recognition that no evaluation of the good, the beautiful, or the right is possible without its alter: the evil, the ugly, and the wrong. Disgust is the negative that permits desire and delight to be perceptible. Not only this, but it acts as a curb on them, for Menninghaus, like Kolnai and Kant before him, is acutely interested in disgust as a product of satiation, the sense of having had enough — or too much — of a good thing. He refines and makes sense of Kolnai's notion of aversion to overabundant life by noting that the real problem is not the fecundity of the world, but rather the way in which the world's desirables cannot help but offer themselves to be consumed: "The problematic, disgust-endangered moment of satiation is not the 'enough' of joyful satisfaction, but the 'too much' unfolding in just that satietory moment - namely, to the extent that the object of already fulfilled desire offers itself to further consumption" (2003: 27). The prospect of consumption 
past the point of satiation is the moment that occasions a sense of contamination, of the breaking down of distinctions, alternatives, and hierarchies of value.

\section{HOLDING THE EXCESS OF SIMILARITY AT BAY}

Which brings me back to what these theories of disgust might offer toward addressing the problem of repugnance in PNG courts, and particularly the three themes that I pulled from my representative cases: the relative degrees of sophistication, the safeguarding of humanity, and the rejection of relationships that appear analogous to slavery. These are the indices of particular humanistic values that are upheld by means of the repugnancy clause in general and its moral-aesthetic valence in particular. The disgust value of repugnance is what produces the segregating and ordering effect of the clause as judges have invoked it, in that it separates out particular actions as customary, as rules that cannot be integrated into the "underlying law," and finally relegates them to a domain of ancestral action overridden by a legal dispensation that may be conceived variously as modern, humanistic, liberal, Christian, or some combination of these. That the position taken by judges in their use of the clause is not one held universally or even widely by the populace of PNG is precisely the point: judges and their legal colleagues are explicitly engaged in a project of determining what the future of a Papua New Guinean nation ought to be. The values emergent in their use of the repugnancy clause are tools for the clearing away of a particular sort of past in order to create a particular sort of future. It is important to remember that the elements of the past to be cleared away, however, include the ancestry of what is now called "law" as well as what is called "custom."

Let me conclude this essay by suggesting that the three themes I have identified all enable the invocation of repugnance in its moral-aesthetic sense because they offer the potential for a disgust response in specific ways. First, they point to the pre-independence desire of Europeans in PNG to distinguish themselves and their practices from Papua New Guineans and theirs, and in this respect there is a parallel with what Povinelli has observed in Australia. But there is more to it than that; the laws, policies, and more general normative orders of European colonials in PNG and in neighboring Southeast Asia reveal a more than passing preoccupation with "contamination" or unacceptable similarity between local people and Europeans (e.g., Inglis 1975; Stoler 1989). The fear of contamination, quite physically realized in laws such as the White Women's Protection Ordinance in the Territory of Papua, points to precisely the ambivalence of disgust residing in most if not all of the accounts I have reproduced above; one would not reject or resist something that does not, in some way, fascinate or attract. And this simultaneous attraction-repulsion works both ways, of course. Unlike almost every other postcolonial Commonwealth state, PNG never got rid of its colonial-era repugnancy clause, which 
has repeatedly and earnestly been adopted by Papua New Guinean judges and lawmakers since its inclusion in the Constitution.

I submit here the possibility that two important things are happening when repugnance appears in PNG courts in relation to representations made on behalf of customary law. The first and easier claim to make is that judges, as representatives of the emergent PNG middle class, deploy the moral-aesthetic value of repugnance in order to establish a space in which a pan-Papua New Guinean Christian modernity, where persons have ownership of and are responsible for their own bodily resources, can flourish. Abjected from this space are all those Papua New Guineans whose subject positions are presumed still hopelessly mired in obligations to kin, subsistence horticulture, local exchange, or ritual complexes, and an inadequacy of educational attainment or Christian commitment. There is some evidence to support this sort of claim in the literature (Gewertz and Errington 1999; Robbins 2005; Street 2010). And in my own fieldwork with PNG legal elites in 2008, my preliminary queries about the enduring invocation of the repugnancy clause and the dual usage of repugnance were met with mild astonishment. "Do you really think we should continue having polygamy in this country?" responded one colleague, the then-Secretary to the Constitutional and Law Reform Commission of PNG, when I asked him why the Commission was submitting a brief to the country's Supreme Court advocating for a discussion of the outlawing of polygamy. He went on to tell me that polygamy was discriminatory against women, made politicians vulnerable to bribery because they required exorbitant sums of money to pay bridewealth for their many wives, and was furthermore un-Christian. All of these factors made it repugnant to the National Goals and Directive Principles of PNG - a solidly legal argument from a legal colleague, but I could not help noticing that the energy with which he made the argument also suggested polygamy's repugnance to his own person, as one of those persons responsible for shaping PNG's future as a modern, liberal, Christian country. ${ }^{6}$ I had also heard the "polygamy encourages political corruption" argument from a law professor at the University of Papua New Guinea, indicating that what an anthropologist might quaintly consider a localized form of social organization had become for legal specialists a moral calamity affecting the nation as a whole.

\footnotetext{
${ }^{6}$ I thank Dr. Lawrence Kalinoe for this illuminating conversation, and apologize to him if I have unintentionally misrepresented what I understood his position to be at the time. Upon reading an earlier draft of this article, Dr. Kalinoe also expressed reservations about its title, since he thought it suggested that the PNG Constitution itself assigned a morally repugnant value to customary law. I hope that the current version of the piece makes clear, to colleagues both within and outside of PNG, that I do realize this is not the case. The title is deliberately provocative in order to ask what factors have historically enabled both anthropologists and judges to invoke simultaneously repugnancy's legal and moral values in relation to the still ambiguous domain of customary law.
} 
But class sensibilities are not sufficient to get us to repugnance, notwithstanding Bourdieu's (1984) salutary reminder of the relationship between class, taste, and other aesthetic values. The second and less intuitive effect (or affect) that may be emerging in the case law is that PNG judges are also endeavoring to differentiate themselves from Europeans. Here I am partly inspired by Motha's (1998) analysis of the Mabo decision in Australia, in which he asserts that, far from signaling the recognition of difference, as the case has been widely understood, it was instead a recognition of sameness. That is, in recognizing the land claim of the Meriam people of the eastern Torres Strait Islands, the court in Mabo caused the Meriam relationship to land to appear in a proprietary form analogous to the European relationship to land. In so doing, it erased any possibility of acknowledging true epistemic difference between European law and Meriam law. "To that extent," Motha writes, "the decision in Mabo is not a cessation of colonialism or a postcolonial moment. It is a continuation of colonial rule whereby the original inhabitants are forced to accept the invader's law and its translation of their relationship to land" (1998: 80).

In a manner resonant with Motha's argument for the effects of Mabo, I have elsewhere argued that the recognition of customary law in PNG first creates custom as a social form analogous to law in order thereby to differentiate it from "received" or "imposed" law (Demian 2011). Having achieved analogic sameness between the two sources of law, lawmakers in PNG must then, in accordance with the directives of the Constitution and the Underlying Law Act, rediscover difference. The repugnancy clause may appear to index only the radical difference of those Papua New Guineans who have, in the eyes of the country's urban elites, made the transition to modernity incompletely. If this were all that were happening, it would mean judges in PNG could only ever look over their own shoulders as it were, erasing the tracks of custom behind them. This does not square with the perspective of the judges and other legal professionals I spoke to, all of whom are striving in earnest to create a future-oriented law for the country. This is why I argue that the use of the repugnancy clause by the PNG judiciary points to still another differentiating move: having achieved sameness through analogizing European and customary law, they must re-differentiate themselves from the European source of law.

The three themes I extracted from the case law in the previous section in actuality point far more accurately to what Europeans were doing in PNG during the colonial era than to what Papua New Guineans themselves have been doing either before or since independence. The preoccupation with levels of "sophistication" or "civilization," beloved of pre-independence judges and racialist theories generally, was precisely what enabled the European appropriation of PNG conceivable in the first place. This preoccupation also, as it happens, formed the basis of the disgust habitually reported by the earlier colonials for their new subjects, lending a certain weight to both Nussbaum's and Miller's assertions that disgust is an affective expression and 
reinforcer of hierarchy. Papua New Guineans found and continue to find reminders of Europeans unwilling or unable to treat or transact with them as fellow human beings, such as the Native Regulations (Papua) and the Native Administration Regulations (New Guinea), the initial resistance to educating Papua New Guineans, or the colonial assumption right up until World War II that Papua New Guineans would never be capable of governing their own country. These reinforced the sentiment prevalent among many Papua New Guineans, past and present, that Europeans and North Americans possess fabulous wealth but are simply disinclined to share it. As for the slavery trope that haunts cases in which custom is found repugnant on the grounds that women are treated as sexual slaves or children as chattel, Papua New Guineans were able to (and to a certain extent, still can) observe this precise configuration of relations among Europeans. They know, too, that Europeans once kidnapped people in parts of their country to be forced labor on nineteenth-century Queensland plantations. These European excesses of the past still threaten to contaminate the present of the Papua New Guinean imaginary, particularly through institutions like the courts that are necessarily a direct inheritance of the colonial era.

To stress the point again, I am not particularly interested in Europeans worried about becoming more like Papua New Guineans, when what appears to be happening is Papua New Guineans worried about becoming more like Europeans. ${ }^{7}$ This is the excess of the colonial inheritance that must be "cleared away," to borrow Kolnai's formulation, from the sight of the contemporary Papua New Guinean state in order to bring into view a Papua New Guinea that is in all respects independent of past relationships.

"I also have problems with that particular clause," a National Court judge told me in a 2008 interview after I brought up the repugnancy clause. He went on to develop a spatial metaphor of people located on the "outside" looking "in." If someone is looking in from outside, he said, they are judging things from a different perspective. So for example, when white people first came to PNG, they did not like women to go around wearing no tops - "they judged us." But now it is accepted, even though most Papua New Guinean women choose to wear tops except at ceremonial occasions or at home in the company of kinfolk. "We were not given a chance to define our custom," he went on; "custom" was determined from the perspective of those standing on the outside. Dancing and carving, too, were once denigrated and discouraged by the churches, he reminded me, but now they are embraced; the

7 At least some evidence for this can be found in the early writings by the first wave of PNG's political and legal elite, which simultaneously acknowledged the debt PNG's legal system owed its common law inheritance, yet expressed concern that a "Melanesian way" of settling disputes and maintaining social cohesion was at risk of being overrun or displaced by this inheritance. See, in particular, Kaputin 1975, and Narokobi 1983, for instances of this debate. 
value of the practices has changed. "Repugnancy is based on whoever is making the judgments," the judge concluded. ${ }^{8}$ It was clear at this point that he was using repugnancy in its moral or aesthetic sense, by means of enumerating some of the Papua New Guinean practices which were deemed inappropriate, immoral, or "backward" during the colonial era, and which are now held up as exemplars of the value of custom. Assuming that I took his meaning correctly, the problem this member of the judiciary had with the repugnancy clause was that it could never quite shed the legacy of that era, the non-legal semantic freight of morality, or indeed the problem of perspective itself: who is to say that a judge from one part of the country might not take issue with customary law professed for another part of the country?

Repugnance, as it has been doubly employed in PNG case law, points to a desire for connections with a wider legal and political world that custom simply cannot provide. Custom is too problematically anchored to particular places and particular times, especially in cases where litigants claim different, and conflicting, items of custom from different parts of the country. It is for this reason that the judge cited above suggested to me that "the imposed law"that is, the common law introduced in the colonial era-had more legitimacy in the eyes of many people. As he framed the problem, the "dangers" of custom were that, especially in urban settlements, what custom would people apply? ${ }^{9}$ If custom is as fluid as everyone seems to agree that it is, people can and do devise customs to suit their needs. What custom would the court be considering? "Does it have a root?" as this judge put it, or might it be somebody's own invention? "Sooner or later we might not know what we are talking about, and then we will go back to the imposed law." In the judge's opinion, custom held out too much scope for manipulation, while "the imposed law" was reliable, independent of individual invention, and even reflected some cultural values, such as in the Criminal Code. "It's independent; it has a source," he concluded. This was a powerful statement. In it, the judge suggested that people might be more willing to rely on law whose source-the common law-was not tied to any particular place within PNG, and so was not vulnerable to manipulation by persons claiming expertise from that place. It also does not privilege the custom of one place over that of another place within the country. The "source" of the common law, external to PNG entirely, is precisely what endows it with legitimacy and efficacy.

And this leads back to the latent paradox within the repugnancy clause, and within the very proposition of including something called "customary law" within the Constitution of PNG. Custom is, by its very nature in

\footnotetext{
8 All quoted material from P. Mogish personal communication, 18 Aug. 2008.

9 Goddard has already elucidated some of the problems with this very issue, and the creativity brought to bear upon it by Village Court magistrates working in ethnically diverse urban squatter settlements (1996).
} 
Melanesia, tied to place in ways that may be even further inflected by the variables of generation, gender, initiation status, and church affiliation. "Customary law," then, forms a crystallization of these inflections as they are brought to bear on particular court cases. Repugnancy can be invoked if a practice declared as customary law is too shameful. By this I mean that it is too linked to a domain of action that at least some Papua New Guineans would love dearly to see the end of. This is not because it reminds them of who they used to be and what they used to do, but because it reminds them of the world that once refused to conduct relations with them in any terms other than repugnance in the moral sense, and indeed may still. Far from standing for an emplaced history, then, repugnance stands for a history of desire to transcend place. It is precisely this desire that simultaneously lends the power of disgust and repulsion to repugnance, because it is the desire to want to be with or be like people who have never wanted to be with you or be like you.

\section{REFERENCES}

Allott, A. 1970. New Essays in African Law. London: Butterworths.

Banks, C. 1998. Custom, Compensation and the Criminal Law (Compensation) Act1991 of Papua New Guinea. British Journal of Criminology 38, 2: 299-316.

Banks, C. 2001. Women, Justice and Custom: The Discourse of "Good Custom" and "Bad Custom" in Papua New Guinea and Canada. International Journal of Comparative Sociology 42, 1-2: 101-22.

Bell, D. 1998. Ngarrindjeri Wurruwarrin: A World that Is, Was, and Will Be. North Melbourne: Spinifex Press.

Bennett, T. W. 2004. Customary Law in South Africa. Lansdowne: Juta and Company Ltd.

Bourdieu, P. 1984. Distinction: A Social Critique of the Judgement of Taste. London: Routledge \& Kegan Paul.

Corrin Care, J. and J. G. Zorn. 2001. Legislating Pluralism: Statutory "Developments" in Melanesian Customary Law. Journal of Legal Pluralism and Unofficial Law 46: 49-101.

Demian, M. 2003. Custom in the Courtroom, Law in the Village: Legal Transformations in Papua New Guinea. Journal of the Royal Anthropological Institute 9, 1: 97-115.

Demian, M. 2006. Reflecting on Loss in Papua New Guinea. Ethnos 71, 4: 507-32.

Demian, M. 2011. "Hybrid Custom" and Legal Description. In J. Edwards and M. Petrović-Šteger, eds., Recasting Anthropological Knowledge: Inspiration and Social Science. Cambridge: Cambridge University Press.

Dinnen, S. 1988. Sentencing, Custom and the Rule of Law in Papua New Guinea. Journal of Legal Pluralism and Unofficial Law 27: 19-54.

Filer, C. 1997. Compensation, Rent and Power in Papua New Guinea. In S. Toft, ed., Compensation for Resource Development in Papua New Guinea. Port Moresby: Law Reform Commission (Monograph 6), and Canberra: Australian National University, National Centre for Development Studies (Pacific Policy Paper 24).

Filer, C. 2006. Custom, Law and Ideology in Papua New Guinea. Asia Pacific Journal of Anthropology 7, 1: 65-84.

Fitzpatrick, P. 1999. Passions out of Place: Law, Incommensurability, and Resistance. In E. Darian-Smith and P. Fitzpatrick, eds., Laws of the Postcolonial. Ann Arbor: University of Michigan Press. 
Forsyth, M. 2013. Witchcraft and Sorcery-Related Killings in Melanesia: The Legal Issues. Australian National University: State, Society \& Governance in Melanesia In Brief 2013/1. At: http://ips.cap.anu.edu.au/sites/default/files/SSGM_IB_2013_1_ Proof2_PrintWeb.pdf (accessed 10 Jan. 2014).

Gewertz, D. B. and F. K. Errington. 1999. Emerging Class in Papua New Guinea: The Telling of Difference. Cambridge: Cambridge University Press.

Gluckman, M. 1956. Custom and Conflict in Africa. Oxford: Blackwell.

Goddard, M. 1996. The Snake Bone Case: Law, Custom and Justice in a Papua New Guinea Village Court. Oceania 67, 1: 50-63.

Hviding, E. 1993. Indigenous Essentialism? Simplifying Customary Land Ownership in New Georgia, Solomon Islands. Bijdragen tot de Taal-, Land- en Volkenkunde 149: 802-24.

Independent State of Papua New Guinea. 1971. Sorcery Act. At: http://www.paclii.org/ pg/legis/consol_act/sa1971117/ (accessed 11 Jan. 2014).

Independent State of Papua New Guinea. 1975. Constitution. At: http://www.paclii.org/ pg/legis/consol_act/cotisopng534/(accessed 11 Jan. 2014).

Independent State of Papua New Guinea. 2000. Underlying Law Act. At: http://www. paclii.org/pg/legis/consol_act/ula2000173/(accessed 11 Jan. 2014).

Inglis, A. 1975. The White Women's Protection Ordinance: Sexual Anxiety and Politics in Papua. London: Chatto and Windus for Sussex University Press.

Kaputin, J. 1975. The Law: A Colonial Fraud? New Guinea 10: 4-15.

Kolnai, A. 2004. On Disgust. Chicago: Open Court.

Leslie, R. D. 1977. The Repugnancy Rule in African Law and the Public Policy Rule in Conflict of Laws. Acta Juridica 1977: 117-27.

Lev, D. S. 1985. Colonial Law and the Genesis of the Indonesian State. Indonesia 40: $57-74$.

Llewellyn, K. N. and E. A. Hoebel. 1941. The Cheyenne Way: Conflict and Case Law in Primitive Jurisprudence. Norman: University of Oklahoma Press.

Malinowski, B. 1926. Crime and Custom in Savage Society. London: Routledge \& Kegan Paul.

Menninghaus, W. 2003. Disgust: The Theory and History of a Strong Sensation. Albany: State University of New York Press.

Merry, S. E. 2009. Relating to the Subjects of Human Rights: The Culture of Agency in Human Rights Discourse. In M. Freeman and D. Napier, eds., Law and Anthropology: Current Legal Issues, Volume 12. Oxford: Oxford University Press.

Miller, W. I. 1997. The Anatomy of Disgust. Cambridge: Harvard University Press.

Motha, S. 1998. Mabo: Encountering the Epistemic Limit of the Recognition of "Difference." Griffith Law Review 7, 1: 79-96.

Motha, S. 2005. The Failure of "Postcolonial" Sovereignty in Australia. Australian Feminist Law Journal 22: 107-26.

Mydans, S. 1997. When the Bartered Bride Opts out of the Bargain. New York Times, 6 May: A4.

Narokobi, B. 1983. The Melanesian Way. Port Moresby: Institute of Papua New Guinea Studies.

Nussbaum, M. C. 2004. Hiding from Humanity: Disgust, Shame, and the Law. Princeton: Princeton University Press.

Ottley, B. 1995. Looking Back to the Future: The Colonial Origins of Current Attitudes toward Customary Law. In J. Aleck and J. Rannells, eds., Custom at the Crossroads in Papua New Guinea. Port Moresby: Faculty of Law, University of Papua New Guinea.

Ottley, B. 2002. Reconciling Modernity and Tradition: Papua New Guinea's Underlying Law Act. Reform 80: 22-25, 70-71. 
Povinelli, E. 2002. The Cunning of Recognition: Indigenous Alterities and the Making of Australian Multiculturalism. Durham: Duke University Press.

Read, J. S. 1972. Customary Law under Colonial Rule. In H. F. Morris and J. S. Read, Indirect Rule and the Search for Justice: Essays in East African Legal History. Oxford: Clarendon Press.

Robbins, J. 2005. The Humiliations of Sin: Christianity and the Modernization of the Subject among the Urapmin. In J. Robbins and H. Wardlow, eds., The Making of Global and Local Modernities in Melanesia: Humiliation, Transformation and the Nature of Cultural Change. Farnham: Ashgate.

Roberts-Wray, K. 1966. Commonwealth and Colonial Law. London: Stevens \& Sons.

Rubin, L. 1965. The Adaptation of Customary Family Law in South Africa. In H. Kuper and L. Kuper, eds., African Law: Adaptation and Development. Berkeley: University of California Press.

Slaats, H. and K. Portier. 1993. Sorcery and the Law in Modern Indonesia. In C. W. Watson and R. Ellen, eds., Understanding Witchcraft and Sorcery in Southeast Asia. Honolulu: University of Hawai'i Press.

South African Law Commission. 1999. The Harmonisation of the Common Law and the Indigenous Law: Report on Conflicts of Law. Project 90. At: http://www.justice.gov. za/salrc/reports/r_prj90_conflict_1999sep.pdf (accessed 11 Jan. 2014).

Stoler, A. 1989. Making Empire Respectable: The Politics of Race and Sexual Morality in 20th-Century Colonial Cultures. American Ethnologist 16, 4: 634-60.

Strathern, M. 1999. Property, Substance and Effect: Anthropological Essays on Persons and Things. London: Athlone Press.

Strathern, M. 2004. Losing (out on) Intellectual Resources. In A. Pottage and M. Mundy, eds., Law, Anthropology, and the Constitution of the Social: Making Persons and Things. Cambridge: Cambridge University Press.

Street, A. 2010. Belief as Relational Action: Christianity and Cultural Change in Papua New Guinea. Journal of the Royal Anthropological Institute 16, 2: 260-78.

Strelein, L. 2004. Symbolism and Function: From Native Title to Aboriginal and Torres Strait Islander Self-Government. In M. Langton, M. Tehan, L. Palmer, and K. Shain, eds., Honour among Nations? Treaties and Agreements with Indigenous People. Melbourne: University of Melbourne Press.

Wastell, S. 2007. Being Swazi, Being Human: Custom, Constitutionalism and Human Rights in an African Polity. In M. Goodale and S. E. Merry, eds., The Practice of Human Rights: Tracking Law between the Global and the Local. Cambridge: Cambridge University Press.

Weiner, J. F. 1999. Culture in a Sealed Envelope: The Concealment of Australian Aboriginal Heritage and Tradition in the Hindmarsh Island Bridge Affair. Journal of the Royal Anthropological Institute 5, 2: 193-210.

Weiner, J. F. 2006. Eliciting Customary Law. Asia Pacific Journal of Anthropology 7, 1: $15-25$.

Weisbrot, D. 1988. Papua New Guinea's Indigenous Jurisprudence and the Legacy of Colonialism. University of Hawai'i Law Review 10, 1: 1-45. 
Abstract: The Constitution of Papua New Guinea (PNG) features a peculiar artifact of colonial-era law known as a repugnancy clause. This type of clause, used elsewhere as a neutral mechanism to identify conflicts between legal provisions, has in PNG become a tool for the moral-aesthetic evaluation of "customary law." In this article, I follow the history of the PNG repugnancy clause from its colonial origins and through the relevant case law since the country's independence in order to ask both how the clause acquired its non-legal meaning through legal usage, and why it has been retained in its original form in PNG when so many postcolonial legal regimes have discarded it. Comparative material from Indonesia, sub-Saharan Africa, and especially Australia is used to contextualize the durability of the PNG repugnancy clause, and theoretical material on the affect of disgust and shame is brought to bear in order to understand the use of repugnancy in its moral-aesthetic sense. The article concludes with a meditation on the way the repugnancy clause has enabled the judiciary of PNG to distance the law of the country not simply from an uneducated or inadequately Christian general populace, but also from a history in which all Papua New Guineans were regarded as a contaminating threat to the European colonizers whose legal system the country has inherited. 